\title{
Evaluasi Kandungan Coliform dan Salmonella Pelet Limbah Penetasan dengan Aditif Zeolit pada Lama Penyimpanan Berbeda
}

\section{(The Evaluation of Coliform and Salmonella Content on Hatchery Waste Pellets with Zeolite Additives in Different Times of Storage )}

\author{
Sudarwanto M, Sulistiyanto B, Sumarsih S \\ Fakultas Peternakan dan Pertanian, Universitas Diponegoro, Semarang \\ msudarwanto1808@gmail.com
}

\begin{abstract}
The study to examine an ability of zeolites on suppressing the growth of Coliform and Salmonella in the hatchery pellets during storage was conducted at the Feed Technology Laboratory, Faculty of Animal Agriculture Sciences, Diponegoro University. The zeolite has been reported has a special ability to absorb substances, exchange ions and as a catalyst. This zeolite was expected suppress the growth of pathogenic bacteria, thus elongated life time as well as maintained quality of the pellet. In the pelleting process, the hatchery waste was added with $0 \%$ and 3\% zeolites, then the pellets were stored for 4, 8, and 12 weeks, with 3 replicates of each treatment combinations. Data were statistically analyzed by ANOVA. Results of experiments showed that addition of zeolite in the pelletizing hatchery waste do not influence the content of Coliform in the pellets during storaging and the Salmonella maintained to be negatives. However, the average number of Coliform bacteria remained on the critical category of safety standard of feedstuffs i.e. $10^{5} \mathrm{cfu} / \mathrm{g}$. It could be concluded that pelleting was effective suppressed growth of Coliform and Salmonella, but an addition of zeolite was not effective in inhibiting the growth of pathogen on the hatchery waste pellets during storage.
\end{abstract}

Key Words: Zeolite, Storage, Coliform and Salmonella Content, Hatchery Waste Pellets

\begin{abstract}
ABSTRAK
Penelitian untuk menguji kemampuan zeolit dalam menekan pertumbuhan Coliform dan Salmonella pada pelet limbah penetasan selama penyimpanan dilakukan di Laboratorium Teknologi Pakan, Fakultas Peternakan dan Pertanian, Universitas Diponegoro. Zeolit telah dilaporkan memiliki kemampuan khusus untuk menyerap zat, menukar ion dan sebagai katalisator. Zeolit ini diharapkan dapat menekan pertumbuhan bakteri patogen sehingga dapat memperpanjang masa simpan serta mempertahankan kualitas pelet. Dalam proses peleting, limbah penetasan ditambahkan dengan 0 dan 3\% zeolit, kemudian pelet disimpan selama 4, 8, dan 12 minggu, dengan 3 ulangan dari masing-masing kombinasi perlakuan. Data dianalisis dengan ANOVA. Hasil percobaan menunjukkan bahwa penambahan zeolit dalam proses peleting limbah penetasan tidak berpengaruh terhadap kandungan Coliform dalam pelet selama penyimpanan dan Salmonella negatif. Jumlah rata-rata bakteri Coliform berada pada kategori kritis standar keamanan bahan pakan yaitu $10^{5} \mathrm{cfu} / \mathrm{g}$. Dapat disimpulkan bahwa perlakuan peleting efektif menekan pertumbuhan bakteri Coliform dan Salmonella, namun penambahan zeolit tidak efektif dalam menekan pertumbuhan patogen pada pelet limbah penetasan selama penyimpanan.
\end{abstract}

Kata Kunci: Zeolit, Penyimpanan, Kandungan Coliform dan Salmonella, Pelet Limbah Penetasan

\section{PENDAHULUAN}

Bahan inkonvensional yang belum termanfaatkan dengan maksimal adalah limbah penetasan yang diantaranya telur gagal tetas, cangkang telur, dan DOC afkir. Produksinya limbah penetasan diperkirakan mencapai 3,3 milyar ton dengan asumsi daya tetas $50-80 \%$ 
(FAO 2011). Kandungan nutrisi limbah penetasan sendiri cukup baik yaitu protein kasar $(\mathrm{PK}) \pm 20 \%$ dan lemak kasar (LK) 9\% (Wardana et al., 2016). Hasil evaluasi nilai biologis menunjukkan kenaikan berat badan ayam broiler secara signifikan lebih tinggi dalam ransum yang mengandung $12 \%$ tepung limbah penetasan dibandingkan dengan tepung ikan dengan jumlah yang sama. Rasio efisiensi protein tepung limbah penetasan dibandingkan dengan tepung ikan masing-masing adalah 3,96:2,85; kecernaan protein 86,02 : 71,9; pemanfaatan protein bersih $64,9: 42,37$ dan nilai biologis 75,37 : 58,84 yang menunjukkan keseimbangan yang lebih baik dari asam amino pada tepung limbah penetasan dibandingkan dengan tepung ikan (Rasool et al., 1999). Kadar air dari limbah penetasan $\pm 40 \%$ yang menyebabkan bakteri mudah untuk tumbuh dan berkembang. Oleh karena itu diperlukan penanganan lebih lanjut agar bahan pakan tersebut aman untuk diberikan kepada ternak dan kualitasnya dapat terjaga dalam masa penyimpanan.

Selain aspek nutrisi, keamanan pakan juga perlu diperhatikan sebagai pakan yang dikonsumsi ternak. Keamanan pakan sendiri salah satunya dapat dilihat dari kandungan bakteri patogen, diantaranya yang paling umum adalah bakteri Coliform dan Salmonella. Kandungan air limbah penetasan yang tinggi mengakibatkan mudahnya bakteri tumbuh dan berkembang serta menimbulkan bau yang tidak sedap. Oleh karena itu dibutuhkan pengolahan lebih lanjut dengan penambahan zeolit dan peleting agar memperbaiki kelayakan pakan dan memperbaiki tampilan. Zeolit merupakan mineral yang dihasilkan dari proses hidrothermal pada batuan beku basa (Bell 2001). Zeolit dilaporkan sangat efektif dalam menyerap nitrat dan amoniak (Mažeikiene et al. 2008), serta menekan Salmonella dan memperbaiki pertumbuhan broiler (Al-Nasser et al. 2011). Zeolit dalam berbagai laporan mampu menekan pertumbuhan Salmonella, menurunkan jumlah E. coli, dan meningkatkan $\mathrm{pH}$ rumen. Selain itu zeolit mampu mengikat senyawa kimia beracun dan menekan aktivitas mikroorganisme. Penelitian pendahuluan Wardana et al. (2016) mencatat bahwa perlakuan peleting dengan penambahan zeolit berpengaruh sangat nyata dalam menekan kandungan Coliform dan terbukti dapat menghilangkan Salmonella. Pelet merupakan bentuk massa bahan pakan yang dipadatkan dengan tekanan tinggi melalui lubang cetakan dengan ukuran tertentu (Ensminger 1985). Pelet umumnya berbentuk bulat panjang dan lebih dikenal dengan pakan komplit (complete feed) karena tersusun atas berbagai bahan pakan, baik pakan berserat maupun konsentrat serta mengandung kadar gizi yang seimbang guna memenuhi kebutuhan ternak. Pemanasan dan tekanan tinggi pada proses peleting, terbukti tidak merusak ketersediaan asam amino, maupun kemanfaatan energi bahan, (Serrano et al. 2013).

Bahan pakan maupun produk pakan yang disimpan akan mengalami penurunan mutu yang dapat disebabkan oleh enam faktor utama, yaitu massa oksigen, uap air, cahaya, mikroorganisme, kompresi atau bantingan, dan bahan kimia toksik (Herawati, 2008 dalam Solihin et al., 2015). Oleh karena itu diperlukan usaha penyimpanan yang baik agar mutu bahan pakan tetap terjaga dengan baik sesuai mutu bahan pakan saat panen maupun saat diproduksi (Mukodiningsih et al., 2014). Penggunaan zeolit sebagai aditif dalam proses peleting diharapkan dapat memperbaiki kualitas mikrobiologis dari pelet limbah penetasan sekaligus mampu mempertahankan mutu pelet selama masa penyimpanan.

\section{MATERI DAN METODE}

Penelitian dilaksanakan pada bulan Oktober sampai dengan Desember 2016 di Laboratorium Teknologi Pakan, Fakultas Peternakan dan Pertanian, Universitas Diponegoro, Semarang. 


\section{Materi}

Materi penelitian adalah limbah penetasan (telur gagal tetas, cangkang telur, dan DOC afkir), zeolit serta onggok. Alat yang digunakan adalah ember dan plastik, blender, mesin pengering, pelleter, peralatan analisis mikroba (tabung reaksi, cawan petri, pipet ukur, bunsen, spinball, inkubator).

\section{Metode}

Limbah penetasan ayam yang terdiri atas cangkang telur (30\%), telur gagal menetas $(60 \%)$ dan DOC afkir (10\%) mengacu pada komposisi limbah yang dihasilkan oleh hatchery, dihancurkan dengan menggunakan blender. Selanjutnya ditambah filler onggok $10 \%$ dan dicampur rata. Untuk perlakuan dengan zeolit bahan yang telah tercampur rata selanjutnya ditambahkan zeolit 3\% (berat/berat) dicampur hingga rata. Campuran dengan dan tanpa zeolit selanjutnya dilakukan proses penyesuaian $\left(80-90^{\circ} \mathrm{C}\right.$ selama 15 menit). Pencetakan pelet dilakukan dengan menggunakan ekstruder dengan spesifikasi gear box 1:30 ukuran 50, dengan ukuran diameter lubang cetakan $6 \mathrm{~mm}$ dan panjang pelet $3 \mathrm{~cm}$. Pengeringan pelet menggunakan mesin pengering aliran udara panas (air dryer) dengan suhu $40-45^{\circ} \mathrm{C}$, sampai kadar air pelet berkisar antara $10-15 \%( \pm 24$ jam). Penyimpanan pelet dilakukan dengan cara memasukkannya ke dalam botol jam ukuran $200 \mathrm{ml}$, menutup botolnya dan menyimpannya pada suhu ruangan antara $20-25^{\circ} \mathrm{C}$ untuk lama waktu yang berbeda yaitu penyimpanan selama 4, 8 dan 12 minggu sebagai perlakuan faktor 2 .

Tahap selanjutnya yaitu analisis mikrobiologi meliputi total bakteri Coliform dan Salmonella. Metode perhitungan jumlah koloni mengikuti Standard Plate Count (Fardiaz, 1993). Untuk menguji bakteri Coliform pada sampel pelet limbah penetasan dimulai dengan menyiapkan empat tabung reaksi yang telah di sterilkan dan memberi tanda pada masing masing tabung dengan tanda $10^{-1}$ sampai dengan $10^{-4}$. Kemudian masing-masing tabung diisi dengan $9 \mathrm{cc} \mathrm{NaCl} \mathrm{0,85}$ steril secara aseptis, sampel pelet dihaluskan dan ditimbang seberat 1 gram kemudian dimasukan ke dalam tabung reaksi dengan label $10^{-1}$ dan di homogenkan. Setelah homogen, ambil $1 \mathrm{cc}$ dari tabung tersebut, dimasukan ke dalam tabung reaksi dengan label $10^{-2}$ dan dihomogenkan. Dari tabung tersebut diambil 1 cc, kemudian dimasukan ke dalam tabung reaksi dengan label $10^{-3}$ dan dihomogenkan. Tabung terakhir diambil $1 \mathrm{cc}$ dan dimasukan pada tabung reaksi dengan label $10^{-4}$ dan dihomogenkan. Cawan petri yang telah disterilkan sebanyak empat buah kemudian diberi label tanda $10^{-1}$ sampai dengan $10^{-4}$ dan 1 blangko. Masing masing diambil dengan pipet $0,1 \mathrm{cc}$ sesuai dengan label, dan di tuangkan kedalam cawan petri sesuai dengan label yang telah di berikan. Pada blangko dimasukan $0,1 \mathrm{cc} \mathrm{NaCl} \mathrm{0,85}$ secara steril. Chromucul Coliform Agar (CCA) suhu $40-42^{\circ} \mathrm{C}$ sebanyak $\pm 15 \mathrm{cc}$ ditambahkan dan dihomogenkan. Kemudian didiamkan sampai agar membeku. Inkubasi media dalam inkubator pada suhu $37^{\circ} \mathrm{C}$ selama 18-24 jam. Dilakukan penghitungan jumlah koloni yang tumbuh pada setiap pengenceran dengan mengikuti Standard Plate Count (SPC).

Uji Salmonella dimulai dengan menghaluskan sampel kemudian menimbang 1 gram sampel yang telah halus serta melarutkanya ke dalam media BHIB sampai larut sempurna. Sampel diinokulasikan menggunakan jarum OSE yang sudah dilarutkan pada media MacConkey. Media MacConkey diinkubasikan pada suhu $37^{\circ} \mathrm{C}$ selama $18-24$ jam dalam inkubator. Koloni yang tumbuh pada media kemudian diamati. Koloni Salmonella pada media Mac Conkey memiliki ciri-ciri berbentuk bulat, berwarna putih, tepi berlobang, elevas cembung dan konsistensi lunak. Koloni yang memiliki ciri tersebut kemudian diambil dengan jarum OSE dan diinokulasikan pada media uji biokimia. Media uji biokimia di inkubasi selama 17-24 jam dalam ikubator. Hasil uji biokimia dapat dibaca 
dengan menambahkan lima tetes Kovack's pada media indol, lima tetes alfa naphtol 5\% dan $\mathrm{KOH}$ keratin $40 \%$ masing masing lima tetes pada media Voges-Proskauer (VP) dan tambahkan 5 tetes reagen Methyl Red (MR) pada media MR.

\section{Analisis data}

Data yang diperoleh dianalisis dengan menggunakan analisis varian (analysis of variance/ANOVA) Rancangan Acak Lengkap (RAL) pola faktorial $2 \times 3$ (penambahan zeolit $0 \%$ dan $3 \%$ dengan lama penyimpanan 4 , 8, dan 12 minggu) dengan taraf signifikasi $5 \%$ untuk mengetahui pengaruh nyata perlakuan.

\section{HASIL DAN PEMBAHASAN}

\section{Kandungan Coliform}

Rataan kandungan bakteri Coliform pelet limbah penetasan dapat dilihat pada Tabel 1 . Hasil analisis ragam menunjukan tidak ada interaksi antara lama penyimpanan dan penambahan zeolit terhadap kandungan bakteri Coliform pada pelet limbah penetasan.

Tabel 1. Kandungan bakteri Coliform pelet limbah penetasan

\begin{tabular}{lcccc}
\hline \hline \multirow{2}{*}{$\begin{array}{l}\text { Penambahan } \\
\text { zeolit }\end{array}$} & \multicolumn{3}{c}{ Lama penyimpanan (minggu) } & \multirow{2}{*}{ Rata-rata } \\
\cline { 2 - 4 } & 4 & 8 & 12 & \\
\cline { 2 - 4 } $0 \%$ & $4,0 \times 10^{6}$ & $6,5 \times 10^{4}$ & $3,3 \times 10^{4}$ & $1,4 \times 10^{6}$ \\
$3 \%$ & $9,9 \times 10^{5}$ & $7,5 \times 10^{4}$ & $5,9 \times 10^{4}$ & $3,7 \times 10^{5}$ \\
\hline Rata-rata & $2,5 \times 10^{6}$ & $7,0 \times 10^{4}$ & $4,6 \times 10^{4}$ & \\
\hline
\end{tabular}

$\mathrm{CV}=18$; Anova dengan transformasi log 10 (taraf signifikasi 5\%)

Hasil penelitian menunjukan bahwa masih terdapat bakteri Coliform pada setiap sampel percobaan, penambahan zeolit 3\% tidak berpengaruh nyata $(\mathrm{p}>0,05)$ terhadap kandungan bakteri Coliform pada pelet limbah penetasan. Hal ini tidak sesuai dengan pendapat Eng et al. (2003) yang melaporkan bahwa penggunaan zeolit $2 \%$ dalam ransum dapat menekan jumlah bakteri Coliform. Belum efektifnya zeolit dalam menekan kandungan Coliform dimungkinkan kualitas zeolit masih kurang, mengingat zeolit yang digunakan adalah zeolit alam yang tidak dilakukan proses aktivasi sebelumnya.

Rataan kandungan bakteri Coliform pada pelet limbah penetasan dengan penambahan zeolit belum termasuk aman digunakan sebagai bahan pakan untuk ternak karena masih diatas ambang batas kandungan bakteri yang diperbolehkan. Sementara rataan kandungan Coliform pasca penyimpanan 8 dan 12 minggu, tergolong aman. Menurut standar SNI (2014) jumlah bakteri dalam pakan akan membahayakan bagi ternak yang mengkonsumsinya apabila mencapai $10^{5} \mathrm{cfu} / \mathrm{g}$.

\section{Kandungan Salmonella}

Identifikasi kandungan bakteri Salmonella pada pelet limbah penetasan yang diberi aditif zeolit 0 dan $3 \%$ serta disimpan dalam waktu yang berbeda dapat dilihat pada Tabel 2. Hasil uji menunjukan bahwa semua sampel yang diujikan tidak terdapat kandungan bakteri Salmonella. 
Tabel 2. Identifikasi kandungan bakteri Salmonella pelet limbah penetasan

\begin{tabular}{lccc}
\hline \multirow{2}{*}{ Penambahan zeolit } & \multicolumn{3}{c}{ Lama penyimpanan (minggu) } \\
\cline { 2 - 4 } & 4 & 8 & 12 \\
\hline $0 \%$ & Negatif & Negatif & Negatif \\
$3 \%$ & Negatif & Negatif & Negatif \\
\hline
\end{tabular}

Identifikasi kandungan Salmonella menunjukan hasil yang negatif pada setiap sampel dengan zeolit 3\% maupun 0\% dan pada semua level penyimpanan yang berbeda sekalipun. Penelitian Wardana (2016) menunjukkan bahwa bahan dasar awal yaitu limbah penetasan menunjukan adanya kandungan bakteri Salmonella, meskipun tidak diketahui dengan pasti. Hal ini dapat disebabkan oleh proses peleting yang optimal dan proses penyimpanan yang baik sehingga mampu menghambat ataupun menghilangkan kandungan Salmonella. Proses peleting dengan atau tanpa penambahan zeolit 3\% dan proses penyesuaian pada suhu $80^{\circ} \mathrm{C}$ efektif membunuh bakteri Salmonella.

Menurut Adlim (2007) bakteri Salmonella akan mati pada suhu $60^{\circ} \mathrm{C}$ jika dipanaskan selama waktu 5 menit dan akan mati lebih cepat pada suhu diatasnya. Selama waktu penyimpanan tidak terjadi pencemaran bakteri Salmonella diakibatkan oleh kemampuan zeolit sebagai mineral absorben serta mekanisme penyimpanan yang baik. Al-Nasser et al. (2011) melaporkan bahwa penambahan zeolit dalam ransum dapat menekan jumlah Salmonella. Pada penelitian ini pelet limbah penetasan disimpan dalam botol jam yang rapat sehingga kadar air dapat terjaga stabil dan pertumbuhan bakteri dapat ditekan.

Menurut Champ dan Highley (1987) kesuksesan penyimpanan tergantung pada kontrol serangan serangga dan mempertahankan tingkat kadar air, mulai dari kehilangan sampai perpindahan cairan yang dapat terjadi secara signifikan. Apabila dilihat dari standar keamanan pakan menurut SNI (2014) pakan yang aman adalah yang bebas dari kandungan bakteri Salmonella, dengan demikian pelet limbah penetasan tersebut aman digunakan sebagai pakan pada ternak.

\section{KESIMPULAN}

Dapat disimpulkan bahwa perlakuan peleting efektif menekan pertumbuhan bakteri Coliform dan Salmonella, namun penambahan zeolit tidak efektif dalam menekan pertumbuhan patogen pada pelet limbah penetasan selama penyimpanan.

\section{UCAPAN TERIMA KASIH}

Ucapan terima kasih kami sampaikan kepada Laboratorium Teknologi Pakan Fakultas Peternakan dan Pertanian Universitas Diponegoro atas fasilitas yang telah diberikan. Terima kasih kepada Rektor UNDIP atas dukungan dana penelitian melalui hibah kompetitif penelitian mahasiswa, serta kepada Muhammad Khoiruddin, Bima Siswoaji, Yuli Eko, Atiya Inayati, dan Mega Hardianti atas kerjasamanya dalam pelaksanaan penelitian ini.

\section{DAFTAR PUSTAKA}

Adlim A.I.S. 2007. Studi histopatologi organ hati broiler yang diberi pakan silase dan ditantang Salmonella typhimurium [Skripsi]. [Bogor (Indonesia)]: Institut Pertanian Bogor. 
Al-Nasser AY, Al-Zenki SF, Al-Saffar AE, Abdullah FK, Al-Baho ME, Mashaly M. 2011. Zeolit as a feed additive to reduce Salmonella and improve production performance in broilers. Int $\mathbf{J}$ Poult Sci. 10:448-454.

Bell RG. 2001. What are zeolites [internet]. [cited 20 Oct 2016]. Available from: www.Bza.org/zeolites.html.

Champ BR, Highley E. 1987. Bulk handling and storage of grain in the humid tropics. Proceedings of an International Workshop. Malaysia.

Eng KS, Bechtel R, Hutchenson D. 2003. Adding a potassium, clinoptilolite zeolite to feedlot rations to reduce manure nitrogen losses and its impact on rumen $\mathrm{pH}$, E. coli, and performance [internet]. [cited 2 Apr 2017]. Available from: infohouse.p2ric.org/ ref/43/42677.pdf.

Ensminger ME. 1985. Processing effects on nutrition. In: McEllhiney RR, editor. Feed manufacturing technology III. Virginia (US): FAO. p. 529-533.

FAO, 2011. FAOSTAT [internet]. [cited 28 Oct 2016]. Food and Agriculture Organization of the United Nations. Available from: http://www.feedipedia.org/node/212.

Fardiaz, S. 1993. Analisis mikrobia pangan. Bogor (Indonesia): Pusat Antar Universitas Pangan dan Gizi, Institut Pertanian Bogor.

Mažeikiene A, Valentukevičiene M, Rimeika M, Matuzevičius AB, Dauknys R. 2008. Removal of nitrates and ammonium ons from water using natural sorbent zeolit (clinoptilolite). J Environ Eng Land Man. 16:38-44.

Mukodiningsih S, Sutrisno CI, Sulistyanto B, Prasetiyono BWHE. 2014. Pengendalian mutu pakan. Semarang (Indonesia): UPT Undip Press.

Rasool S, Rehan M, Haq A, Alam MZ. 1999. Preparation and nutritional evaluation of hatchery waste meal for broilers. Asian-Australasian J Anim Sci. 12:554-557.

Serrano MP, Frikha M, Corchero J, Mateos GG. 2013. Influence of feed form and source of soybean meal on growth performance, nutrient retention, and digestive organ size of broilers 2 battery study. Poult Sci. 92:693-708.

SNI. 2014. Standar Nasional Indonesia 7991. Tepung hasil ikutan unggas (poultry byproduct meal) - Bahan pakan ternak. Jakarta (Indonesia): Badan Standardisasi Nasional.

Solihin, Muhtarudin, Sutrisna R. 2015. Pengaruh lama penyimpanan terhadap kadar air kualitas fisik dan sebaran jamur wafer limbah sayuran dan umbi-umbian. J Ilmiah Peternakan Terpadu. 3:48-54.

Wardana BA, Sulistiyanto B, Sumarsih S. 2016. Pengaruh penambahan zeolit pada proses pelletizing limbah penetasan terhadap kandungan Coliform dan Salmonella produk pelet. J Agripet. 16:42-48.

\section{DISKUSI}

\section{Pertanyaan}

1. Apakah fungsi yang diharapkan dari penambahan zeolit?

2. Mengapa penggunaan zeolit tidak signifikan dalam menekan pertumbuhan bakteri?

3. Bagaimana cara mengaktivasi zeolit? 


\section{Jawaban}

1. Penggunaan zeolit diharapkan berfungsi sebagai absorben atau penyerap yang dapat menyerap air dan bakteri sehingga menjaga kualitas mikrobiologis dan kualitas pelet limbah penetasan selama disimpan.

2. Hal tersebut kemungkinan karena zeolit yang digunakan belum melalui aktivasi terlebih dahulu sehingga fungsinya belun optimal.

3. Dengan dipanaskan pada suhu $200-400^{\circ} \mathrm{C}$ atau dengan aktivasi kimiawi menggunakan larutan asam $\mathrm{H}_{2} \mathrm{SO}_{4}$ atau basa $\mathrm{NaOH}$. 